DOI https://doi.org/10.18551/rjoas.2021-01.19

\title{
CHANGES IN THE HISTOPATHOLOGY OF THE GILLS AND LIVER OF TILAPIA (O. NILOTICUS) INFECTED WITH AEROMONAS HYDROPHILA
}

\author{
Wattimury Dougklas ${ }^{1,7}$, Laishevtcev Alexey ${ }^{2,3}$, Yanuar Uun $^{4}$, Hardoko $^{5}$, Andayani Sri $^{6}$ \\ ${ }^{1}$ Department of Marine Science, Faculty of Fisheries and Marine Science, \\ University of Brawijaya, Indonesia \\ ${ }^{2}$ Federal Scientific Center - All-Russian Research Institute of Experimental Veterinary \\ Medicine named after K.I. Skryabin and Y.R. Kovalenko of the Russian Academy \\ of Sciences, Moscow, Russia \\ ${ }^{3}$ Laboratory of Biological Control and Antimicrobial Resistance, Orel State University \\ named after I.S. Turgenev, Orel City, Russia \\ ${ }^{4}$ Department of Aquatic Resource Management, Faculty of Fisheries and Marine Science, \\ University of Brawijaya, Indonesia \\ ${ }^{5}$ Department of Fishery Product Technology, Faculty of Fisheries and Marine Science, \\ University of Brawijaya, Indonesia \\ ${ }^{6}$ Department of Aquaculture, Faculty of Fisheries and Marine Science, \\ University of Brawijaya, Indonesia \\ ${ }^{7}$ Department of Marine Science, Faculty of Fisheries and Marine Science, \\ University of Papua, Manokwari, West Papua, Indonesia
}

\begin{abstract}
This research aims to investigate the pathological abnormalities of tilapia (O.niloticus) infected with Aeromonas hydrophila and to observe histopathology, including histological changes in the gills, kidneys, and liver. The results were then explained using descriptive methods. Fish samples were obtained from the Fish Seed Center, Faculty of Fisheries and Marine Sciences, Sumber Pasir Village, Malang Regency, East Java. Histopathology results from infected fish showed necrosis and hemorrhage in the gills and liver.
\end{abstract}

\section{KEY WORDS}

Aeromonas hydrophila, O. niloticus, gills, kidneys, liver.

Tilapia (O. niloticus) is one of the most cultivated species worldwide because it is a source of protein, has a high growth rate, and can adapt to extreme environmental conditions. Therefore, it becomes one of the most in-demand cultivated freshwater aquaculture industries because of its high economic value (FAO, 2017). However, the development of the aquaculture industry has resulted in the emergence of several identified parasites which can cause a decrease in fish production. Infection of O.niloticus by A.hydrophila bacteria is an example of parasites. It has been reported to cause diseases such as Motile Aeromonas Septicemia (MAS) (Plumb, 1999), Hemorrhagic Septicemia, or Red-Sore Disease (Yardimci \& Aydin 2011). A. hydrophila is a gram-negative rod-shaped bacteria found within the water and may perhaps inside fish, and in unstable conditions. It can cause death due to secondary infection (Laith AR \& Najiah M 2013). Thus, this study aimed to examine the clinical symptoms and some pathological changes of O.niloticus fish due to $A$. hydrophila infection.

\section{MATERIALS AND METHODS OF RESEARCH}

Fish samples were obtained from the Fish Seed Hall, Faculty of Fisheries and Marine Sciences, Sumber Pasir Village, Malang Regency, East Java. It was conducted in November - December 2019. The fish were collected and then brought to the Fish Reproduction Laboratory of the Faculty of Fisheries and Marine Sciences and tested with A.hydrophya bacteria. A positive control was used to represent not-infected fish. All procedures have been 
followed and approved by the ethics commission of Universitas Brawijaya and followed international standard rules.

Histological analysis, including gills, liver, and kidney, was carried out by referring to the Stoskopf method (1993). The sample fixation process was carried out for 24 hours using a $10 \%$ formalin solution. The next steps were sample dehydration, clearing, paraffin infiltration, blocking, cutting the target tissue, and staining and installing. The histological features of each organ were analyzed following Allan's (1992) point of view. Sample visualization was carried out using a light microscope. Histopathological analysis was based on Costa (2018), Genten et al. (2009)

\section{RESULTS AND DISCUSSION}

In general, normal gills are characterized by four-gill arches on each side of the buccal cavity. Each arch consists of many gill filaments with two rows of secondary lamellae perpendicular to each filament. Secondary gill lamellae cells are arranged contractile and separated by capillary channels (Peebuaa, et al., 2006).
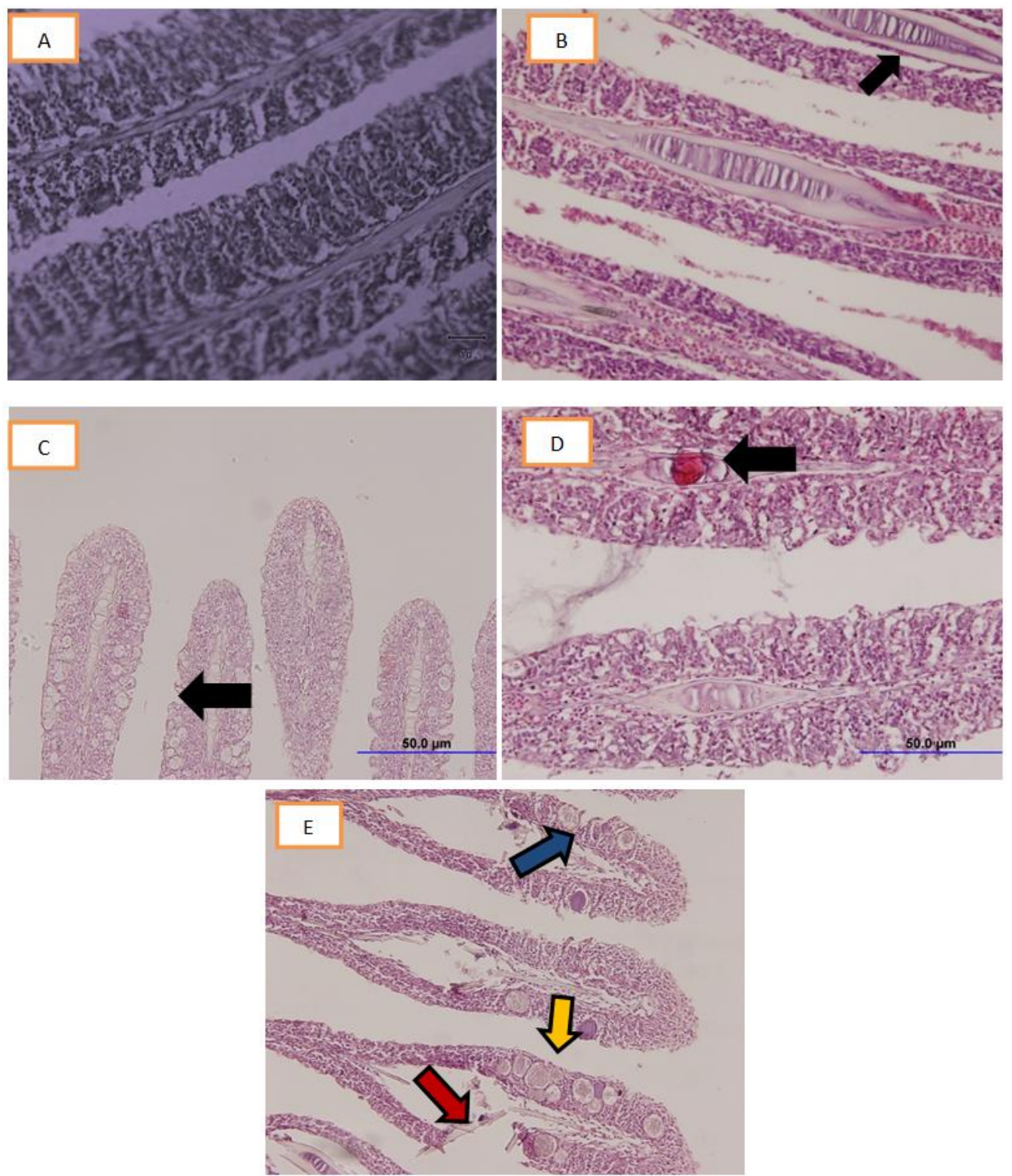

Figure 1 - Histological structure of the kidney: Normal kidney structure (A), Edema (B), Fusion of Secondary Lamela (C), Congestion (D), Hyperplasia (E), Necrosis, Telangiectasis and Epithelium Rupture (F). X 400 magnification 
Normal gills in healthy fish show a neat and easily distinguishable order of the primary and secondary lamellae. Damaged gills begin with congestion and hyperplasia (Figures 1c and 1d), namely the blood accumulation that does not have similarity to normal gills (Figure 1a). Edema appears in damaged gills by fluid infiltration into the tissues (Figure 1b). Corrosion occurs secondarily to the lamellae in the absence of platelets so that it seems empty with only a small amount of fluid. This indicates that edema is an early sign of inflamed fish (Sukarni, 2012) that triggers necrosis or epithelial cell death. Subsequent cell death will lead to hyperplasia, namely a buildup of blood that triggers the secondary lamella's swelling and rupture (Figure 1 b).

Hyperplasia is a passive process that causes blood congestion caused by decreased blood flow in the venous tract (an increase in blood volume in the vessels located in the gill lamellae).
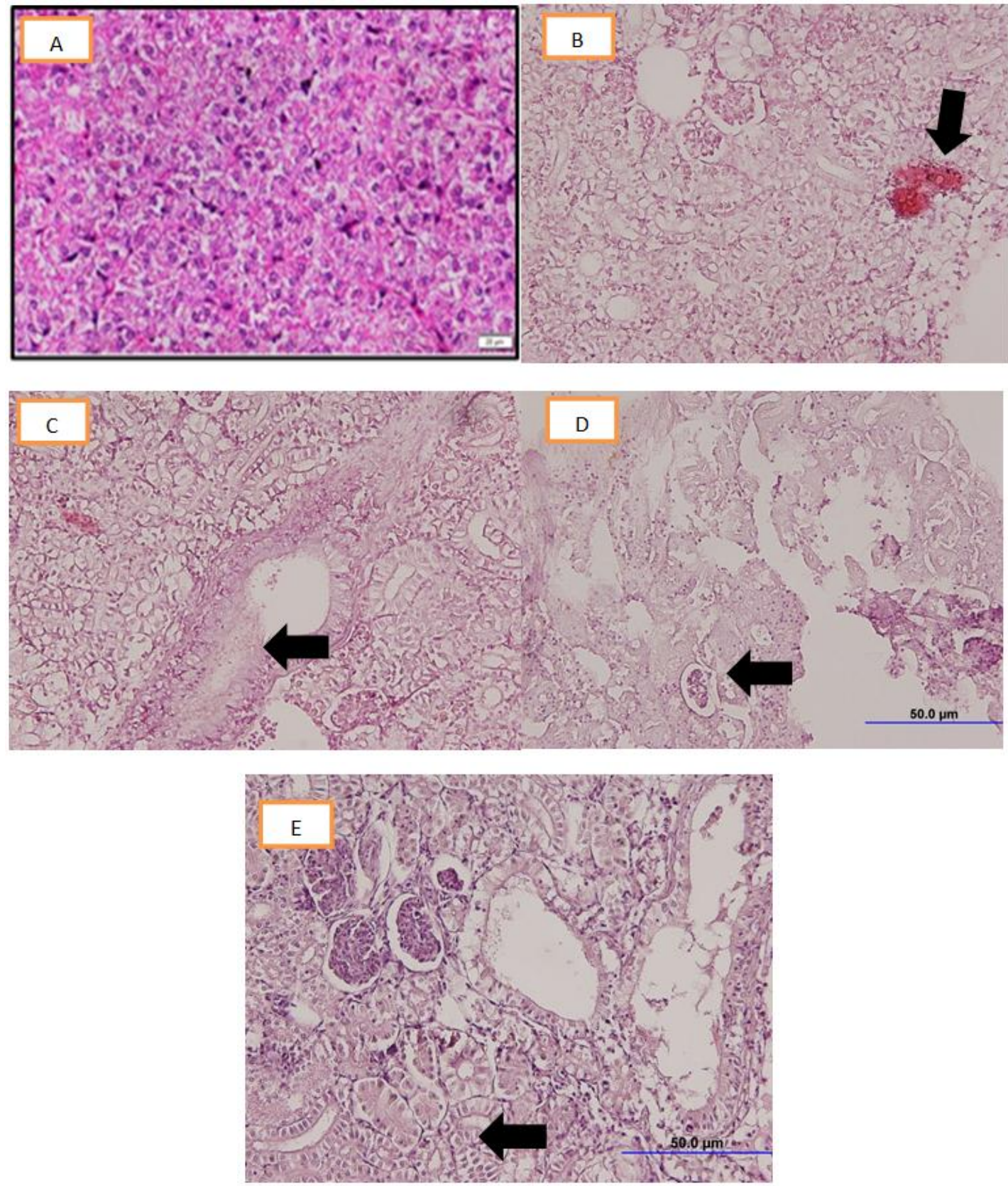

Figure 2 - Kidney histological structure. Normal kidney histology (A), hyperplasia droplet degeneration and deformation in renal tubules architecture (B), necrosis (C), Dilation of Bowman's space (D), Necrosis and renal tubules (E), X 400 magnification 
Changes such as removal of the epithelium can be caused by hyperplasia and hypertrophy. Partial fusion of multiple secondary lamellae is an example of a fish defense mechanism. The jam shows a red color with the density depending on the severity of the infection. Another sign of kidney damage is telangiectasis (1c).

The color density depends on blood oxygenation level. Therefore, in the marginal tract (telangiectasia), erythrocyte congestion usually occurs (Kan, 2012).
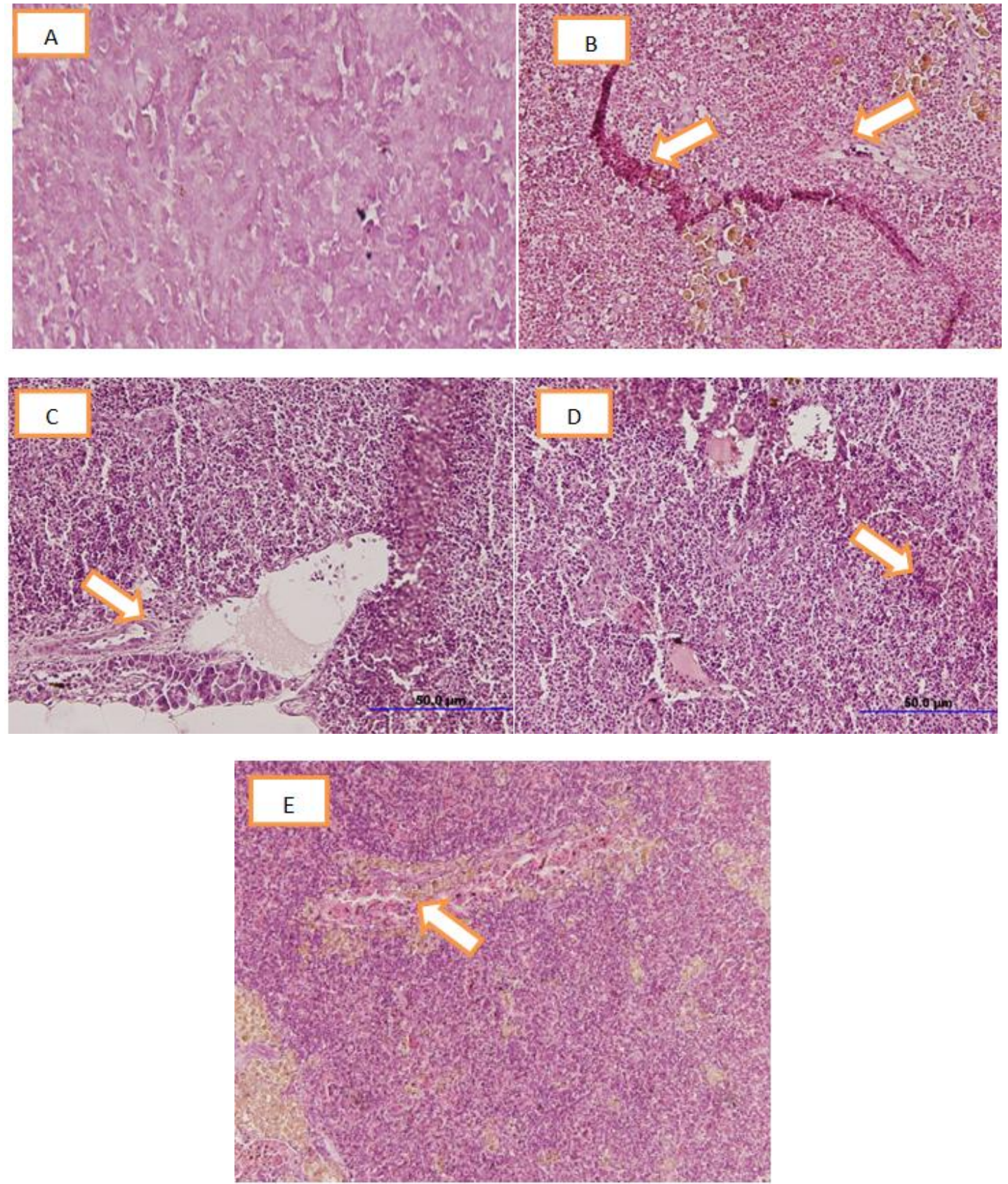

Figure 3 - Histological structure of the liver: normal liver histology (A), Congestion (B), Hypertrophy (C), Vacuole (D), Melanomacrophage aggregate (E)

It was formed hyperplasia in the kidney, especially in the renal tubules, necrosis, bowman's dilation of the renal tubules. Figure b. Hyperplasia of the kidney within the cells or reabsorption indicates damage within the cell (Takashima \& Hibiya, 1995). (C) Irregular renal tubular diameter, glomerular expansion, renal cell damage characterized by severe degeneration in tubular cells. Increased tubule size refers to hydropic swelling. (D) Besides, there was an infiltration of edematous fluid between tubules and bleeding, and diffusion of 
erythrocytes in the interstitial fluid (Thophon et al., 2003). There was a reduction in renal damage characterized by necrosis (D). Other changes observed were cell hypertrophy, and small granules in the cytoplasm appeared like a net (E).

Normal blood can be seen in Figure A. Pathological abnormalities show the blood vessels and glomerulus (B) that cause damage. Therefore, it appears cytoplasm of hepatocytes containing lipids and glycogen associated with the liver's normal metabolic function (C). It also indicates an imbalance between the level of substance synthesis in parenchymal cells and the release rate to the systemic circulation, which can cause overall metabolic damage (Pacheco and Santos, 2002). An increase in cellular size generally characterizes hypertrophy. A. hydrophila causes proliferation of the endoplasmic reticulum membrane (B). Bile stagnation and diffusion of melanomacrophages in the liver parenchyma tissue in organs show the density of aggregated melanomacrophages generally associated with lesions and necrotic (E) (Fanta et al., 2003).

\section{CONCLUSION}

Based on the research results, it can be concluded that there are histological changes between the infected fish of each treatment.

\section{CONFLICT OF INTEREST}

All authors state that there is no conflict in writing this article. Research ethical standards have followed all research procedures as well as an international guide to animal research.

\section{REFERENCES}

1. W.-K.Ng, N.Romano.(2013) A Review of The Nutrition and Feeding Management of Farmed Tilapia Throughout The Culture Cycle.Rev.Aquacult.5 220-254, https://doi.org/10.1111/raq.12014.

2. FAO, 2017.Statistics and Information Branch, Fisheries and Aquaculture Department/

3. FAO.Fishery and Aquaculture Statistics.Global Production by Production Source 19502015 (FishstatJ).FAO Fisheries and Aquaculture Department (online), Rome.

4. Plumb JA. Health maintenance and principal microbial diseases of cultured fishes.Ames, lowa: lowa State University Press; 1999. p.328.

5. Yardimci B, Aydin Y.2011.Pathological findings of experimental Aeromonas hydrophila infection in Nile tilapia (Oreochromis niloticus).Ankara Üniv Vet Fak Derg.58:47-54.

6. Janda J M, Abbott SL.2010.The Genus Aeromonas: Taxonomy, pathogenicity, and infection.Clin Microbiol Rev.23:35-73.

7. Laith AR, Najiah M.2013.Aeromonas hydrophila: Antimicrobial susceptibility and histopathology of isolates from diseased catfish, Clarias gariepinus (Burchell). J Aquacult Res Dev.5:215.

8. I.Zorrilla, M.Chabrill_on, S.Arijo, P.Dıaz-Rosales, E.Martınez-Manzanares, M.Balebona, et al., Bacteria recovered from diseased cultured gilthead sea bream (Sparus aurata L.) in southwestern Spain, Aquaculture 2018 (2003) 11-20.

9. Banu YARDIMCI, YIImaz AYDIN.2011.Pathological findings of experimental Aeromonas hydrophila infection in Nile tilapia (Oreochromis niloticus).Ankara Üniv Vet Fak Derg, 58, 47-54.

10. Peebuaa P.; Kruatrachuea M.; Pokethitiyooka P.\& Kosiyachindaa P.(2006).Histological Effects of Contaminated Sediments in Mae Klong River Tributaries, Thailand, on Nile tilapia, Oreochromis niloticus.Science Asia, 32, 143-150.

11. Sukarni S, Maftuch M, Nursyam H (2012) Investigation of Ciprofloxacin effect on gill and liver histology of Botia fish (Botia macracanthus, Bleeker) which was infected by Aeromonas hydrophila. J Exp Life Sci 2(1):6-12. 
12. Yeter Kan, Elif Ipek Cengiz, Pelin Ugurlu, Mahmut Yanar.2012. The protective role of vitamin $E$ on gill and liver tissue histopathology and micronucleus frequencies in peripheral erythrocytes of Oreochromis niloticus exposed to deltamethrin. Environmental toxicology and pharmacology 34 ( 2012 ) 170-179.

13. Takashima F.\& Hibiya T.(1995).An atlas of fish histology.Normal and pathological features. 2nd ed.Tokyo, Kodansha Ltd.

14. Thophon S.; Kruatrachue M.; Upathan E.S.; Pokethitiyook P., Sahaphong S.\& Jarikhuan S.(2003). Histopathological alterations of white seabass, Lates calcarifer in acute and subchronic cadmium exposure.Environmental Pollution, 121, 307-320.

15. Pacheco M.\& Santos M.A.(2002).Biotransformation, genotoxic and histopathological effects of environmental contaminants in European eel, Anguilla Anguilla L.Ecotoxicology and Environmental Safety, 53, 331-347.

16. Fanta E.; Rios F.S.; Romao S.; Vianna A.C.C.\& Freiberger S.(2003).Histopathology of the fish Corydoras paleatus contaminated with sublethal levels of organophosphorus in water and food.Ecotoxicology. 